\title{
CHEMISTRY
}

\section{HYDROCHEMICAL AND SANITARY MICROBIOLOGICAL RESEARCH OF THE ELENA HILL SPRING WATERS IN THE NAKHUNAO COMMUNITY OF MARTVILI MUNICIPALITY}

\author{
Manuchar Chiqovani \\ Associate Professor at the Department of Chemistry, Faculty of Exact and Natural Sciences, Akaki \\ Tsereteli State University, Kutaisi, Georgia, ORCID ID: https://orcid.org/0000-0001-8384-7730
}

Manoni Gabelashvili

Associate Professor at the Department of Biology, Faculty of Exact and Natural Sciences, Akaki

Tsereteli State University, Kutaisi, Georgia, ORCID ID: https://orcid.org/0000-0003-2694-8863

\begin{abstract}
Marisabel Zarqua
student, Faculty of Exact and Natural Sciences, Akaki Tsereteli State University, Kutaisi, Georgia, ORCID ID: https://orcid.org/0000-0002-4095-7902
\end{abstract}

\section{Nana Megrelishvili}

Associate Professor at the Department of Chemistry, Faculty of Exact and Natural Sciences, Akaki

Tsereteli State University, Kutaisi, Georgia, ORCID ID: https://orcid.org/0000-0003-1380-8650

DOI: https://doi.org/10.31435/rsglobal_ws/30062020/7101

\section{ARTICLE INFO}

Received: 16 April 2020

Accepted: 11 June 2020

Published: 30 June 2020

\section{KEYWORDS}

Hidrochemical, microbiological, spring waters, mineralization, mesophilic aerobes.

\begin{abstract}
Hydrochemical and sanitary microbiological research of the Elena Hill spring waters in the Nakhunao community of Martvili Municipality was done for the first time.

The content of $\mathrm{Mg}^{2+}, \mathrm{Ca}^{2+}, \mathrm{Fe}^{3+}, \mathrm{HCO}^{3-}, \mathrm{Cl}^{-}$, $\mathrm{I}^{-}$ions was determined. Relatively simple and quick chemical and physico-chemical methods of good repeatability were selected for determination. Biogenic substances were determined by photometric method.

Carbon dioxide, oxygen $\mathrm{BOD}_{5}$ and dry remains were also identified. Sanitary-microbiological studies were performed using the following methods: mesophilic aerobes and facultative anaerobes: МУК, 2.1.4 1184-03, common coliform bacteria - МУК 4.2. 1018-01 and Escherichia coli - 18963-73. Based on the experimental data, it was found that the spring water that being researched is low-mineralized, which is why their reaction is almost neutral. The above-mentioned ionic content in the studied spring waters is within the norm, and in some samples (mesophilic aerobes and facultative anaerobes, common coliform bacteria) are established that microbiological, such a marginal concentration of pollution that is harmless for human health and its use in drinking and agricultural terms is within the norm.
\end{abstract}

Citation: Manuchar Chiqovani, Manoni Gabelashvili, Marisabel Zarqua, Nana Megrelishvili. (2020) Hydrochemical and Sanitary Microbiological Research of the Elena Hill Spring Waters in the Nakhunao Community of Martvili Municipality. World Science. 6(58), Vol.1. doi: 10.31435/rsglobal_ws/30062020/7101

Copyright: (C) 2020 Manuchar Chiqovani, Manoni Gabelashvili, Marisabel Zarqua, Nana Megrelishvili. This is an open-access article distributed under the terms of the Creative Commons Attribution License (CC BY). The use, distribution or reproduction in other forums is permitted, provided the original author(s) or licensor are credited and that the original publication in this journal is cited, in accordance with accepted academic practice. No use, distribution or reproduction is permitted which does not comply with these terms. 
Introduction. Water is the source of life and it is a building material used by all organisms, water brings the necessary substances into the body and takes out everything unnecessary. Water is a universal solvent. It is of great importance in a person's daily life. It is one of the most important unchangeable resources and invaluable wealth of our planet. It has always been considered as the first source of life. Water is used widely and in many ways. From the day of its origin, man has been influencing the biosphere, using its resources, which has led to some changes in the biosphere. Thus the problem of environmental protection is of vital importance, especially by means of the importance of water. Rational use and protection of water resources is crucial.

Chemically pure water does not exist in nature. While moving in the earth's crust, water touches many minerals, dissolves them, and carries them along the entire path of circulation. Natural water is a solution that contains substances of different nature and condition, so the study of natural waters requires knowledge of the basic properties of the solutions [1].

Martvili district is located in the north-eastern part of western Georgia, in the Odisha lowlands (southern part) and in front side of the Egrisi ridge mountain (central part) and its southern slopes (northern part). It is bordered on the north by Lentekhi, on the east by Khoni and Tsageri, on the south by Abasha, on the west by Senaki and Chkhorotsku districts. The southern part of the Martvili area is occupied by a lowland, which rises from 60 to $170 \mathrm{~m}$ from southwest to northeast. The highest point is located at 3003 meters above sea level. To the south-west of the Martvili area lies the Askha Mountain Massif, which is rich with karst caves, waterfalls, mineral deposits and building stones. Lebarde's "Chegola" and the Dviri Mountains are rich with healing mineral waters. The beautiful valleys of the plants on the shore create wonderful relief formations, small river plains and table-lands where excellent gardens are cultivated on the alluvial soils of hundred years. The rivers Tekhuri and Abasha, which originate from the Egrisi ridge, flow onto the territory of the municipality [2].

The village of Nakhunao is mountainous, Elena Hill is 150 meters above sea level. Four pure cold springs flow down from Elena Hill. The places where the springs come out from the ground are 900 meters away from each other.

Calcium and magnesium ions are the leading ions in low-mineralized waters. Magnesium and calcium salts determine the constant and temporary hardness of water. An increase in mineralization leads to a decrease in calcium content which is caused by low solubility of $\mathrm{CaCO}_{3}$ and $\mathrm{CaSO}_{4}$. However, the amount of magnesium and calcium in chloride waters increases because $\mathrm{MgCO}_{3}$ is well soluble in water, unlike calcium carbonate and sulfate [3]. Calcium content in river waters does not exceed $250 \mathrm{mg} / 1$. Magnesium and calcium content in underground water is much higher [4]. The content of magnesium, calcium and iron in fresh water depends on the type of soil, the season and the time of day or night.

One of the main tasks in the research of water composition is to determine the content of ions, the analysis is based on the specific properties of each ion and determines their concentration. Some ions are highly toxic, and because of their presence, water can be useless for drinking. Ions may not be poisonous, but it may worsen the physical and organoleptic properties of water. For example, iron is not a poisonous substance, so water containing it has no toxic effects. Nevertheless, the presence of iron ions in water is undesirable. If its content exceeds $0.3 \mathrm{mg} / 1$, the water is unsuitable for drinking and household use. Such water has a brownish-brown and metallic taste. When snow and rain water hit the ground, it washes away sand and clay particles, this particles are difficult to be soluble in water and therefore they stay in a floating condition. The presence of floating substances in the water makes it useless for drinking and household use [1].

Important microorganisms in the formation of the chemical composition of water, use mainly organic substances in the water as nutrients and transform them into minerals, Therefore, the sanitarymicrobiological research of spring, well and network waters is an interesting thing. As much as underground waters polluted by fecal masses, which are used by humans for various purposes, can cause intestinal infections, damage the urinary tract and genitals, or cause bacteremia, poisoning and much more.

Objective. Our objective was to study hydrochemical and sanitary microbiological research of the Elena Hill spring waters in the Nakhunao community of Martvili Municipality.

Taking into consideration the importance of magnesium, calcium, and iron in leading the vital processes of humans, animals, and plants' organisms, the aim of our study was to research the content of magnesium, calcium, iron, $\mathrm{HCO}_{3}^{-}$-is, $\mathrm{SO}_{4}^{2-}$ - is, $\mathrm{Cl}^{-}$-is , $\mathrm{I}^{-}$- is, $\mathrm{CO}_{2}$, oxygen, $\mathrm{BOD}_{5}$ and 
biogenic elements in the Elena Hill spring waters, in the village of Nakhunao, Martvili district. The actuality of the issue lies in the fact, that the content of the abovementioned ions was analyzed in these waters for the first time, for which highly sensitive methods were selected.

The experimental part. Methodology for determining chemical elements in the water

Analyzes were conducted in Analytical Chemistry Laboratory of Kutaisi Akaki Tsereteli State University. Methods tested in hydrochemical practice have been used for analysis [6].

The acidity index was measured by a potentiometric method (potentiometer $p H 673-\mathrm{M}$ ).

The mercurymetric method was used to determine chlorides (titrant $0,01 \mathrm{Hg}\left(\mathrm{NO}_{3}\right)_{2}$ ). Indicator diphenyl (carbazole).

Hydrocarbons were determined by the acidimetric method titrant $0.1-0.01 \mathrm{~N} \mathrm{HCl}$ indicator methyl naringerin.

The content of calcium and magnesium, as well as the total hardness of the waters being researched is determined by the complexonometric method (Titrant $0.01 \mathrm{~N}$ Complexon III.). To determine the magnesium ion content, we used an eriochrome black as an indicator, we created the recommended area with an ammoniacal buffer, and we used merexide as an indicator to determine the calcium ion. Alkaline area was created by $2 \mathrm{~N}$ sodium alkali.

Sulfate ions were determined by the classical gravimetric method, a precipitating form is presented by $\mathrm{BaSO}_{4}$.

Common iron in the waters are determined by photometric method after preliminary rusting in the alkaline area (photometric reagent sulfosalicylic acid) (photoelectrocolorimeter).

Carbon dioxide gas was determined by the alkalimetric method. Titrant $0.1-0.01 \mathrm{~N} \mathrm{NaOH}$. Indicator Phenophthalene

We determined the oxidization by the permanganatometric method (oxidant $0,01 \mathrm{~N} \mathrm{KMnO}_{4}$, acidic area. titrant $0,01 \mathrm{~N}_{2} \mathrm{C}_{2} \mathrm{O}_{4}$ ).

Oxygen content and $\mathrm{BOD}_{5}$ were determined by iodometric method (titrant $0,01 \mathrm{~N} \mathrm{Na}_{2} \mathrm{~S}_{2} \mathrm{O}_{3}$ in an alkaline environment $\mathrm{Mn}(\mathrm{OH})_{2}$ oxidized by oxygen dissolved in water and transferred to a fourvalent manganese compound, which is formed in the presence of excess $K I$ in the acidized solution $I_{2}$ ).

The dry residue was determined by the classical gravimetric method.

Iodine ion was determined by the Reznikov method [7] (Titrate $0,01 \mathrm{~N} \mathrm{Na}_{2} \mathrm{~S}_{2} \mathrm{O}_{3}$ ). Oxidized was accompanied by prepared bromine water.

Biogenic substances were determined by photometric method: $\mathrm{NO}_{2}^{-}$membrane reactive, $\mathrm{NO}_{3}^{-}$sodium salicylate, $\mathrm{NH}_{3}$ - Nesler's reagent, $\mathrm{PO}_{4}^{3-}$ - ammonium phosphormolybdate. Sanitarymicrobiological research of the studied water were carried out in the laboratory of microbiology of Akaki Tsereteli State University of Kutaisi and the examination laboratory in "Microbiology" Ltd. Mesophilic aerobes and facultative anaerobes, common coliform bacteria, and Escherichia coli have been studied by using modern methods.

Explanation of the experiment. Thus, $\mathrm{Mg}^{2+}, \mathrm{Ca}^{2+}, \mathrm{Fe}^{3+}, \mathrm{HCO}_{3}^{-}, \mathrm{Cl}^{-}, \mathrm{SO}_{4}^{2-}, \mathrm{CO}_{2}^{-}$were determined for the first time in Elena Hill spring waters in the Nakhunao community of Martvili Municipality, oxidizability, Oxygen content $\mathrm{BOD}_{5}$ dry residue biogenic elements and $I^{-}$ion by chemical and photometric methods. The results of the analysis are given in Table 1.

The spring waters studied by us are low-mineralized $(0.02-0.65 \mathrm{mg} / \mathrm{L})$, so their reaction is almost neutral (5.91-6.28). The ion content is variable.

The largest amount of magnesium ions is found in the northern spring water $0.1000 \mathrm{mg} / 1$. While the least amount is found in the eastern spring water $0.0024 \mathrm{mg} / 1$.

The content of $\mathrm{Ca}^{2+}$ ion is variable as well. A relatively large amount was found in the northern spring water $0.0074 \mathrm{mg} / 1$, and its content is small in the western spring water $0,0016 \mathrm{mg} / \mathrm{l}$.

$\mathrm{Fe}^{3+}$ ion content is big in the western spring water $0,04 \mathrm{mg} / \mathrm{l}$, and its content is small in the northern spring water $0,02 \mathrm{mg} / \mathrm{l}$.

$\mathrm{HCO}_{3}^{-}$ion content is the biggest in the eastern spring water $0,0098 \mathrm{mg} / \mathrm{l}$, the content of hydrocarbon ions is small in the northern spring water $0,0060 \mathrm{mg} / \mathrm{l}$. 
$\mathrm{SO}_{4}^{2-}$ ion high concentration is fixed in the eastern spring water $0,0453 \mathrm{mg} / \mathrm{l}$. A small amount of sulfate ions are contained in the northern spring water $0,0206 \mathrm{mg} / \mathrm{l}$.

Eastern spring water contains a relatively large number of chloride ions $0,0064 \mathrm{mg} / \mathrm{l}$. And its content is less in the southern spring water $0,0046 \mathrm{mg} / \mathrm{l}$.

The highest carbon dioxide content is in the northern spring water $0.0118 \mathrm{mg} / 1$. A small amount of carbon dioxide is contained in the southern spring water $0.0053 \mathrm{mg} / 1$.

Water oxidation is relatively high in the western spring water $2.32 \mathrm{mg} / \mathrm{L}$, its small amount is found in the northern spring water $2.16 \mathrm{mg} / 1$.

Oxygen content is high in the western spring water $14.69 \mathrm{mg} / 1$. A relatively small concentration of oxygen is found in the northern spring water $9.79 \mathrm{mg} / \mathrm{L}$.

$\mathrm{BOD}_{5}$ is $61 \mathrm{mg} / \mathrm{l}$ in the eastern spring water, and it is $-8,16 \mathrm{mg} / \mathrm{l}$ in the northern spring water. $0.21 \mathrm{mg} / 1$.

The dry residue is the highest in the eastern spring water $0.65 \mathrm{mg} / 1$. Its content is the lowest

The content of biogenic elements $\mathrm{NO}_{2}^{-}, \mathrm{NO}_{3}^{-}, \mathrm{NH}_{3}, \mathrm{PO}_{4}^{3}$ at the detection margin is smaller. $I^{-}$ion content is also variable. $I^{-}$is high in the western spring water $4,185 \mathrm{mcg} / \mathrm{l}$. A small amount of iodide ion contains a northern spring water $2,538 \mathrm{mcg} / 1$.

Table 1. Results of hydrochemical analysis of Elena Hill spring waters in village Nakhunao of Martvili region

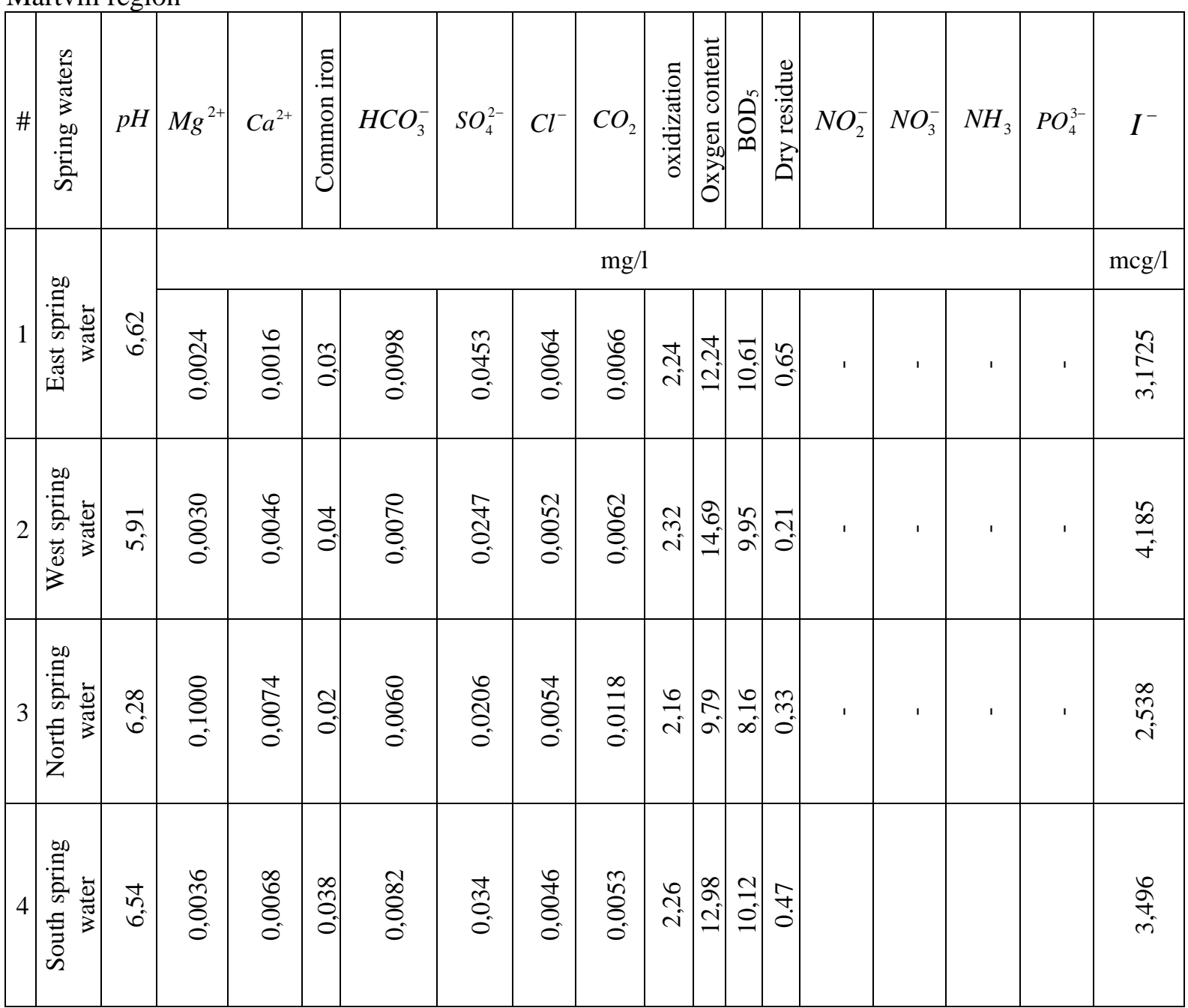

Results of microbiological analysis are given in table 2 . 
Table 2. Results of microbiological analysis of Elena Hill spring waters in village Nakhunao of Martvili region

\begin{tabular}{|c|l|c|c|c|}
\hline$\#$ & \multicolumn{1}{|c|}{$\begin{array}{c}\text { Microbiological } \\
\text { indicators }\end{array}$} & unit of measurement & $\begin{array}{c}\text { Standard not more } \\
\text { than }\end{array}$ & $\begin{array}{c}\text { Result of } \\
\text { examination }\end{array}$ \\
\hline 1 & $\begin{array}{l}\text { Mesophilic aerobes } \\
\text { and facultative } \\
\text { anaerobes }\end{array}$ & $\begin{array}{c}\text { Ktse/ml } \\
37^{\circ} \mathrm{C}\end{array}$ & $\begin{array}{c}20 \\
100\end{array}$ & 32 \\
\hline 2 & $\begin{array}{l}\text { Common coliform } \\
\text { bacteria }\end{array}$ & $300 \mathrm{ml}$ & Not allowed & Was found \\
\hline 3 & Escherchia coli & $300 \mathrm{ml}$ & Not allowed & Was not found \\
\hline
\end{tabular}

Conclusions. The ion content in the above-mentioned studied waters is within the norm and its use for drinking and agricultural purposes is acceptable. The main microbiological indicators in the samples of water being researched are within the norm, only in some samples microbiological pollution is established.

\section{REFERENCES}

1. U. Bregvadze, M. Natadze, Z. Mamulashvili, Water Chemistry and Microbiology, Tbilisi; 1987. pg.5-15.

2. Georgian Soviet Encyclopedia, 1988.v.7.

3. Беленький С.М., Лаврешкина Г.П., Минеральные воды, Москва, «легкая и пищевая промышленность», 1982, с. 30-34.

4. Алекин О.А. Основы гидрохимии, Москва, Ан СССР, 1953, с. 67-69.

5. Privezentsev I., Hydrochemistry of freshwater reservoirs, Tbilisi, Education1990, pg. 64-65.

6. Лурье Ю.Ю. Унифицированные методы анализа вод. -М.: Химия, 1973. -367 с.

7. Резников А., Муликовская Е., Соколов И. Методы анализа природных вод, М, 1970, стр. 261.

8. Справочник по микробиологическим методом исследования. Под редакцией М. О. Биргера, М. 1982. 